\title{
Editorial
}

\section{Corona Virus dan Manajemen Mutu Pelayanan Klinis di Rumah Sakit}

\author{
HANEVI DJASRI ${ }^{1}$ \\ ${ }^{1}$ Pusat Kebijakan dan Manajemen Kesehatan, Fakultas Kedokteran, Kesehatan Masyarakat dan Keperawatan, Universitas Gadjah Mada \\ Yogyakarta
}

Email korespondensi: hanevi.djasri@ugm.ac.id

Beberapa pekan terakhir masyarakat Indonesia dan juga dunia dihebohkan dengan wabah corona virus jenis baru (Novel Corona Virus atau nCoV), atau secara resmi saat ini disebut sebagai COVID-19 yang merupakan kepanjangan dari "coronavirus disease that was discovered in 2019" (World Health Organization (WHO), 2020a) yang juga termasuk keluarga besar dari Corona Virus (CoV).

Sebenarnya beberapa tahun yang lalu juga muncul penyakit serupa yang disebabkan oleh CoV yaitu Sindrom Pernafasan Timur Tengah (MERS-CoV) dan Sindrom Pernafasan Akut Parah (SARS-CoV). Sebagaimana penyakit-penyakit tersebut, COVID-19 juga memiliki tanda-tanda umum infeksi termasuk gejala pernapasan, demam, batuk, sesak napas dan kesulitan bernafas. Pada kasus yang lebih parah, infeksi dapat menyebabkan pneumonia, sindrom pernapasan akut, gagal ginjal, dan bahkan kematian.

WHO dengan segera mengeluarkan pedoman tatalaksana infeksi saluran pernapasan akut berat (severe acute respiratory infection/SARI) yang diduga karena COVID-19. Pedoman tersebut ditujukan untuk para dokter yang merawat pasien di rumah sakit untuk memberikan kemudahan akses terhadap panduan terkini dalam rangka memastikan tatalaksana terbaik bagi pasien.

Pedoman memuat: 1) proses triage untuk mengenali dan menyortir pasien dengan SARI; 2) tindakan segera untuk pencegahan dan pengendalian infeksi dengan tepat; 3) pemberian terapi dan pemantauan; 4) pengumpulan spesimen untuk diagnosis laboratorium; 5) tatakelola gagal napas hipoksemia dan sindrom gangguan pernapasan akut atau acute respiratory distress syndrome/ARDS); 6) manajemen syok septik; 7) pencegahan komplikasi; 8) perawatan khusus anti COVID-19; dan pertimbangan khusus untuk pasien hamil (WHO, 2020b).

Sebagai pengelola rumah sakit, ketersediaan pedoman internasional ini perlu dicermati, diadopsi menjadi pedoman klinis (clinical guidelines), diterapkan dan dievaluasi sebagai bagian dari manajemen mutu pelayanan klinis. Dalam standar akreditasi rumah sakit di Indonesia, penyusunan dan penerapan pedoman klinis memang disyaratkan dalam bentuk Panduan Praktik Klinis (PPK), terlebih untuk tatalaksana pasien dengan risiko tinggi. Standar akreditasi juga meminta agar PPK juga menjadi dasar untuk melakukan evaluasi mutu dan keselamatan asuhan pasien yang diberikan oleh setiap klinisi (KARS, 2019).

Berbagai penelitian telah menunjukkan bahwa penerapan pedoman klinis dapat meningkatkan proses tatalaksana pelayanan klinis maupun luaran (outcome) klinis pada pasien, seperti dapat meningkatkan kepatuhan terhadap prosedur, mengurangi variasi pelayanan yang tidak diperlukan, meningkatkan angka keberhasilan pengobatan atau operasi hingga meningkatkan efisiensi penggunaan sumber daya termasuk dana (Grimshaw dan Russell, 1993). Namun, hal ini tidak mudah.

Penyusunan dan penerapan pedoman klinis di rumah sakit sering menghadapi kendala. Kendala pada proses adaptasi pedoman klinis internasional terkait dengan kemungkinan adanya perbedaan budaya dan organisasi antar negara, hal ini meliputi ketersediaan jenis pemerikasaan diagnostik, pelayanan medis, asuhan keperawatan, dan layanan klinis lainnya, serta juga ketersediaan sumber daya serta nilai, preferensi pasien, dan karakteristik populasi atau prevalensi penyakit (Fervers et al., 2006). Sedangkan kendala pada penerapan umumnya terbagi menjadi 3 faktor (Rauh et al., 2018), yaitu: faktor pribadi dokter pelaksana (pengetahuan dan sikap); faktor yang berhubungan dengan pedoman itu sendiri; dan faktor eksternal (seperti kurangnya sumber daya, kendala organisasi, beban kerja yang berat, norma sosial, dan sebagainya).

Kendala dalam proses penyusunan dapat diatasi dengan memperhatikan berbagai prinsip penting, yaitu menghormati prinsip penyusunan panduan berbasis bukti, menggunaan metode yang andal dan konsisten untuk memastikan kualitas panduan yang disusun, memastikan partisipasi dari para pemangku kepentingan utama agar timbul rasa kepemilikan panduan yang disusun, mempertimbangkan konteks praktik dan kebijakan lokal, menggunakan format yang fleksibel untuk mengakomodasi kebutuhan spesifik, serta menyatakan dan mengakui materi pedoman digunakan sebagai sumber penyusunan panduan (Grimshaw et al., 2004).

Mengatasi kendala tersebut perlu dilakukan intervensi yang efektif dan menggunakan beberapa intervensi sekaligus. Intervensi yang hanya satu jenis seperti sosialisasi panduan klinis dalam bentuk membagikan cetakan panduan atau presentasi yang terlalu bersifat mendikte sering terbukti tidak efektif. Intervensi perlu dipilih dengan menggunakan berbagai 
pendekatan seperti audit klinis, mengembangkan sistem pengingat dan juga memanfaatkan kepemimpinan klinis untuk meningkatkan kepatuhan terhadap panduan (Grimshaw et al., 2004).

Wabah COVID-19 diharapkan dapat juga dijadikan momentum untuk melakukan telaah dan perbaikan pelaksanaan konsep tatakelola klinis yang baik (good clinical governance) sebagai salah satu konsep upaya peningkatan mutu pelayanan klinis. Tatakelola klinis yang baik diawali dengan adanya pedoman klinis yang juga disusun (atau diadaptasi) dengan baik dan kemudian diterapkan secara konsisten.

\section{Referensi}

Fervers, B., Burgers, J. S., Haugh, M. C., Latreille, J., Mlika-cabanne, N., Paquet, L., ..., dan Burnand, B. (2006). Adaptation of Clinical Guidelines: Literature Review and Proposition for a Framework and Procedure. International Journal for Quality in Health Care. 18(3). 167-176. https://doi.org/10.1093/intqhe/mzi108.

Grimshaw, J., Russell, M., dan Ian T. (1993). Effect of Clinical Guidelines on Medical Practice: A Systematic Review of Rigorous Evaluations. The Lancet. 342(8883). 1317-1322. https://doi.org/10.1016/0140-6736(93)92244-N.
Grimshaw, J., Eccles, M., dan Tetroe, J. (2004). Implementing Clinical Guidelines: Current Evidence and Future Implications. The Journal of Continuing Education in the Health Professions. 24. 31-37. https://doi.org/10.1002/chp.1340240506.

Komisi Akreditasi Rumah Sakit (KARS). (2019). Standar Nasional Akreditasi Rumah Sakit (SNARS) (edisi 1.1). Jakarta: Komisi Akreditasi Rumah Sakit.

Rauh, S., Arnold, D., Braga, S., Curca, R., Eckert, R., Fröbe, A., ..., dan Molitor, J. (2018). Challenge of Implementing Clinical Practice Guidelines. Getting ESMO' s Guidelines Even Closer to the Bedside: Introducing the ESMO Practising Oncologists 'Checklists and Knowledge and Practice Questions. ESMO Open. 3(5). 1-4. https:// doi.org/ 10.1136/ esmoopen-2018-000385.

World Health Organization (WHO). (2020a). WHO DirectorGeneral 's Remarks at the Media Briefing on 2019-nCoV on 11 February 2020. Diakses dari https://www.who.int/ dg/ speeches/ detail/whodirector-general-s-remarks-at-the-media-briefing-on-2019-ncov-on11-february-2020.j

World Health Organization (WHO). (2020b). Clinical Management of Severe Acute Respiratory Infection When Novel Coronavirus (2019$\mathrm{nCoV}$ ) Infection is Suspected: Interim Guidance. Diakses dari https://www.who.int/docs/default-source/coronaviruse/clinicalmanagement-of-novel-cov.pdf. 